\title{
Writing the Past: Personal Narrative Voice and Creative Process in Writing a Historical Fiction
}

\author{
Leni Marlina \\ State University of Padang, Indonesia \\ *Corresponding Author: lenimarlina.11@gmail.com
}

Copyright $@ 2014$ Horizon Research Publishing All rights reserved.

\begin{abstract}
Humans always need to learn their past and history in order to face the present and to create the future. Learning about the past through creative works can be done through writing historical fictions. Bennett[2] affirms that the general purpose of the historical fiction is 'to bring history to life by fictionalizing the past and reflecting a specific time period; sometimes done by reconstructing characters, events, movements, ways and spirit of life.' In addition, historical fiction can take various forms and depictions. One of the interesting forms is the historical fiction which potrays the fictional characters in fictional situations, but in the context of a real historical period. Furthermore, the creative writing about the the past can be found in some literary genres such as gothic. The gothic work which has most influenced the author's creative process in writing historical fiction is a classic novel, Horace Walpole's The Castle of Otranto[13]. This gothic novel has many unhistorical elements such as ghosts and other supernatural things. However, Walpole's novel is helpful in understanding an example of historical fiction. Moreover, the novel inspires the author as an emerging writer in constructing the past and to present it to modern readers. This paper contains the author's personal narrative voice and it discusses how Walpole's The Castle of Otranto gives the author inspiration in the creative process of writing a short story entitled "The Grandfather's Story" which brings individual's history by fictionalizing the past in the context of Australian history.
\end{abstract}

Keywords Historical Fictions, Creative Process, Writing The Past, Creative Writing

\section{Introduction}

I do not write a Gothic genre that commonly focuses on terrors. However, the early idea to describe the past in my fiction, "The Grandfather's Story", is inspired after reading some gothic novels. This paper aims to report my reading about one of the Gothics novels, Horace Walpole's The
Castle of Otranto[13]; and to demonstrate my insights about the concept of historical fiction as well as its impact to my creative work in telling the past. In addition, this papers aims to shortly report my short creative process in writing a short story, which is intended to be an alternative of historical fiction. I argue that in the case of Walpole's novel and my work, historical fiction is a story about the current humans' ideas and values, which take places in the past.

\section{Writing the Past through Historical Fiction}

According to Dalton[5], historical fiction can take a number of forms that includes but not limited to some depictions. The first depiction is the real historical figures in the context of the challenges they faced. The second one is the real historical figures in imagined situations. The third one is the fictional characters in documented historical situations. The fourth one is the fictional characters in fictional situations, but in the context of a real historical period. In my work, I apply the last option that is mentioned by Dalton.

To illustrate, I create a historical fiction particularly a short story by depicting fictional characters in fictional situations, but in the context of a real historical period in Australia, "Australian Sorry Day". It is the day when the Australian government apologized for the past policy of "Australian Stolen Generation" which refers to Indigenous Australians who were forcibly removed from their families and communities during 1910 to 1970[8]. Furthermore, my short story employs a half-omniscient narrator to frame the story of of two characters - Paul and Paul's grandfather which takes place in 1998. Then, I use Paul's grandfather as the narrator to frame the story of Paul's (adopted) great grandfather, Samuel, which mostly occurred in 1937 in Moorabbin, Victoria. However, I am not going to explore the detail of real historical periods in my work. Instead, I am interested to apply the mysterious sense of the past of the main character as commonly applied in Gothic literature.

The first time studying historical in my academic journey, 
my attention was attracted by Gothic novels rather than other genres. Gothic literature is mostly believed to have begun in the first year of the publication of The Castle of Otranto. Honestly, I read this novel for the first time in my life as a dull reading. Nevertheless, it conveys the historical narrative of the main character, Manfred, by using unhistorical elements such as mysterious deaths, haunted castle, and other supernatural things.

Furthermore, there are many supernatural elements in The Castle of Otranto such as the moaning and walking portrait, and the apparition of Alphonso the Good. Together with other appearances such as ghosts and strange tombs, the supernatural forces enrich the readers' imagination and at the same time reveal the dark side of humanity[9]. The Castle of Otranto also looks ridiculed for its use of the supernatural, which seems to be used crudely, for instance the case of Walpole's gigantic helmet. However, Walpole's novel strongly involves the reader's imagination, which is central to the Gothic endeavour. Therefore, I am interested in the supernatural manifestations and medieval trappings in Walpole's work.

Inspired by the use of unhistorical elements such as supernatural beings in The Castle of Otranto, I apply the similar way to describe the past life of the main character for my fiction - short story entittled "The Grandfather's Story". My short story is about a slice of life, which belongs to a man whose wife has passed away. Through my narrative, I try to engage the readers in imagining how a life-changing event will affect the main character in the short story.

In the narrative, I try to introduce the short history of Paul's family by formulating a relatively mysterious and supernatural thing experienced by Paul's great grandfather Samuel. The mysterious and supernatural thing can be seen through the characters of a woman and her daughter in the empty old neighbour house; the existence of black cat in Samuel's house; and the disappearance of the woman, the girl and the cat before Samuel lost his consciousness. Unlike the unexplainable of supernatural elements in The Castle of Otranto, the unhistorical elements (supernatural things) in my fiction is offered as an effect of psychological issue hallucination experienced by the main character, Samuel, since he was suffered of his wife's death.

In The Castle of Otranto, Walpole used of the third person to demonstrate the complexity of identity. This third-person point of view enables the character in observing and experiencing simultaneous events. Obviously, the modus operandi of Walpole's novel is a terror or dread. The novel holds my attention through dread of a series of terrible possibilities such as Theodore's execution, the incestuous marriage of Manfred and Isabella, and the casting-off of Hippolyta. In addition, the secret passage ways and caves introduced in the novel do not function merely as settings, but they evoke the world of psychological terror. Hence, I believe for the main character (Manfred), it is necessary to look back into the explanation of past through supernatural beings and terror in order to see the present of his life understandably.
Likewise, I also employ the third person point of view to demonstrate the slice of characters' past life in my fiction. However, I do not intend to evolve the world of psychological terror to my characters. In fact, I prefer to explore the grief of the main character- Paul's (adopted) great grandfather in the past. Moreover, in my fiction, the past Paul's great grandfather is framed through the memory of Paul's grandfather. Munslow [11] shows how memory related to present and past:

Indeed, memory is always invoked when we try to escape the present. But ultimately we cannot escape the present because it is an infinitely small yet eternal point of 'becoming'. It is for this reason that the present always forecloses on the past.

However, I cannot avoid the use of past tense in my creative work. The present tense can function to narrate the story of Paul's (adopted) great grandfather, Sam, from the perspective of Paul's grandfather. In contrast, the present tense cannot work to recall Sam's memory in last few years from the point of view of Paul's grandfather. Thus, I used past tense to recall the memory of Sam as the main character. Consequently, both present tense and past tense are necessary to tell the past, in which the use of present tense can dominate the past tense in representing humans' ideas.

Additionally, MacAndrew[10] perceives The Castle of Otranto as the work that represents current ideas of human beings:

Walpole was able to present his age's concept of human evil--pride, hatred, violence, cruelty, incest--as part of man's psychology. The one kind of romance enabled him to delve into his own subconscious, the other helped him to relate what he found there to the human condition in general. The characters are not very convincingly real, of course, but they are recognizably Eighteenth Century figures embodying current ideas about the human mind.

Reissued in a second edition with a new preface in 1765 , The Castle of Otranto openly advocates a "blend [of] the two kinds of romance, the ancient and the modern" and the former "all imagination and improbability". Furthermore, Hogle[7] views Walpole's The Castle of Otranto and the rest of Gothic genre as the dread of the past and the force of change:

Gothic fictions since Walpole have most often been aspiring but middling, or sometimes upper middle-class, white people caught between the attractions or terrors of a past once controlled by overweening aristocrats or priest (or figures with such aspirations) and forces of change that would reject such a past yet still remain held by aspects of it including desires for aristocratic or superhuman powers.

Correspondingly, Williams[14] views that The Castle of Otranto aims 'to produce the art of a lost and idealized past.' Likewise, I read Walpole's novel as the story of ancient regimes of eighteenth-century Europe which is retold in the 
perspective of modern readers. The novel represents a powerful and engaging response to the complexity of the past in some ways. The writer creates the right moments and uses the castle as a strong central image that links different phases in time. The castle releases characters into the story, obstructs others, and issues the past into the present. Thus, I believe that in the case of Walpole work, historical fiction is likely to be a story about the present of ideas and values of human beings.

Furthermore, Carroll[3] correlated historical fiction to the aspect of reality:

Historical fiction, a widely-read genre, continues to engender contradiction and controversy within the fields of literature and historiography. .... Historical documents may provide a basis for a "true account of the world" in a certain time and place, but they are limited in their capacity to act as a foundation for the exploration of all aspects of reality.

To me, historical fiction is not just about exactness in historical context, figures, and events. Instead, it is the framing of history in order to emphasize the feelings and mental imageries of the characters. Moreover, I think historical fiction is not just about presenting the exactness of public historical facts that are told in the past tense. On the contrary, it is the framing of history in order to emphasize the personal life of characters or specific events in the past in order to be understood in the present.

Correspondingly, De Piérola[6] asserts that 'The historical novel plays an important role in our culture because it allows people to interact with the past in a meaningful way; something factual writing struggles to do.' Furthermore, Slotkin[12] views historical fictions as a poetic work rather than historiographical one:

The truth the novel seeks is poetic rather than historiographical: it sacrifices fidelity to non-essential facts in order to create in the reader a vivid sense of what it may have been like to live among such facts - and also a sense of what those facts mean in some larger sense-and to achieve that in a flash of recognition, rather than as the conclusion to a necessarily laborious argument.

In my work, the purpose of the historical fiction is to bring an individual's history by fictionalizing the past. I try to allow the readers to engage with the past and its relation to the present. In my short story, the short life history of Paul's family is narrated after they watch the video of the former prime minister of Australian, Kevin Rudd, delivering a speech and apologizing for the "stolen indigenous generation" in 1998. However, I do not intend to discuss the detail of the Ausralian historical context in my fiction. Instead, I prefer to explore the detail of fictionalized characters and fictionalized events in the historical context.

In other word, my short story tries to offer the readers the fictionalized past of characters in the context of Australian public history. To emphasize, I try to write a narrative which tells the characters' ideas and values in the past to be experienced by the readers in the present.

\section{Conclusion}

To conclude, reading Gothic novel such as Walpole's The Castle of Otranto assists me in understanding an example of historical fiction. Moreover, the novel inspires me in the way to construct the past and to present it to modern readers. Walpole obviously used the unhistorical or Gothic elements in order to explore the past in The Castle of Otranto. Unlike Walpole's novel, I employ unhistorical elements as the part of the past itself through my creative work. In this case, it is the past of the main character, Paul's (adopted) great-grandfather, which is understood in the present perspective of Paul's grandfather. In brief, I believe that Walpole's The Castle of Otranto and my fiction can be classified as the historical fictions since they contain the narratives which explores current humans' ideas and values that may happen both in the past and in the present.

\section{Appendix}

\section{The Grandfather's Story \\ By Leni Marlina}

"For the pain, suffering and hurt of these stolen generations, their descendants and for their families left behind, we say sorry. To the mothers and fathers, the brothers and sisters,

for the breaking up of families and communities, we say sorry."

(A prime ministerial speech in the House of Representatives)

$$
* 1 *
$$

It is 13 February 2008. Paul and his grandfather together with other thousands of people are watching the big screen on Federation Square, Melbourne. They could see and hear clearly the record of the Prime Minister, Kevid Rudd, who is apologizing for the stolen generation of Indigenous Australians. Tears are cascading on the face of Paul's grandfather when the speech is ended. The speech is so meaningful for the history of his family. Later, Paul's grandfather feels unrelenting pressure in his chest as he keeps something that is supposed to be shared.

Paul's parents were killed in a traffic accident when he was at primary school. Since then Paul has been living with his grandfather. As the grandfather gets older, he takes turn to take care of him. It is almost midnight now, but the grandfather cannot sleep yet.

"Paul, I need to tell you a hidden story now. Would you like to hear me?"

\section{"Why not, Grandpa?}

"Well, I'll tell you what your great-grandfather, Samuel Brenton - Sam, had told me in 1988, when I was 
twenty years old, as young as you. In other words, this is the true-life story of my grandfather. I'll tell you the similar story which he had written on his diary in 1937. Are you ready to listen, Paul?"

"Please remember that you are in Moorabbin, Victoria in August 1937 as you are listening to me," said Paul's grandfather.

"Ok. Please be quick, Grandpa. I'm sleepy but I am curious to know about it," replied Paul.

$$
* 2 *
$$

"Are you thinking of finding a new wife, Sam?" John, Sam's close friend, asks when they are in the backyard garden. The question often rings in Sam's ears. Yet, he is not thinking of getting married again. He wishes his wife were still alive. Next two days would have been her birthday. She would have been a year older and a year sweeter. Sam wishes he could see his wife celebrating her birthday.

Trees become silent as the night falls. Hours have passed by and all is quiet and still. Sam walks into the bedroom. He starts smoking in the dim glow of a single lamp in the corner. He ignores his cough. Something is missing. A feeling of being incomplete haunts him. The clock keeps him awake.

Sam takes an album and looks at his wife in the wedding pictures. He feels his chest growing tight. He rubs his chest and raises his eyes. Tears are cascading from his face and landing on the album. He pushes the curtain aside and glance out of the window. He sees the full moon is shining among the twinkling stars.

"Bring!" The striking alarm clock wakes him up. He reaches for it and switches it off. Then he hears the grandfather clock strike eight. He yawns and forces himself out of bed. He groans and staggers groggily to the living room. First, as if he saw a woman on the coach. He shakes his eyes. In fact, there is nobody in the living room. Sam feels that he lives in a different world since his wife has passed away. He often finds strange things around him as he remembers her. He has told about it to his friend, John. John said that "It's just your hallucinations, mate."

The yowling of the black cat breaks the prevailing stillness of the morning. The cat has been in the house since last week. "Sweet Black Catty" - this is what Sam calls it - soon becomes his new playmate. Wherever he goes around the garden it follows him, jumps over the fence, and disappears until next morning. Sam's wife had a black cat, too. It died as he accidentally locked it in the shed for a month. Thus, his wife got angry at him and did not say anything to him for several days.

$$
* 3 *
$$

Sam is gardening in the backyard as he hears a woman laughing and a kid yelling in the close backyard next door. It is strange. Sam never heard anybody in that house since its previous owner moved out.

Curiously he goes slowly towards the fence and peeps through it. He feels silence is settling over the close backyard. The dust is stirring on its concrete. An old wooden beam is lying among the bushes. He finds nobody there.
Butterflies are flying and bees are buzzing over him. Birds are twittering on twiggy orange trees. The sun is baking the backyard stronger than ever. Sam keeps gardening in the heat. His cheeks are getting hotter. He is sweating as the sunlight keeps flowing down. The sweat is soaking into his collar. It trickles down his spine to his waist. Yet, he keeps busy with green grass and colourful flowers.

The sweet waves of thick scent hit him every single time he passes white roses. They are not just the roses. They are his late wife's favourite ones.

The soft smell of these roses takes him back to his wife. He closes his eyes tightly and recalls a vivid memory, when he had felt warm and safe in his wife's soft arms few years ago. She put her arms around his waist as he was about to smoke. He remembers the way she used to hold his hand and say "Would you please quit smoking. You won't kill our baby through the cigarette's poisons, will you?"

However, Sam cannot stop smoking. He regrets that he never listened to her. After he and his wife finished gardening, they would sip iced tea and eat homemade biscuits. At the end of the day, they used to go for a walk in the bush nearby. They walked hand in hand down the street.

Another time Sam's wife was three months pregnant. It was raining. Whenever it started raining, she used to be outside, ready to feel the first few raindrops. On this day she did not do that. She stood before Sam and looked at him gently. She raised herself on tiptoes and rested her hands lightly on Sam's shoulders. She whispered "There will more cheerful days very soon. We'll have a baby if God's willing." All these years ago seem like only yesterday for Sam.

\section{$* 4 *$}

Sam is above the weakness of telling the details of his wife's death. Briefly, his wife asked Sam to accompany her to come back to England because she wants to visit her parents. Unfortunately, Sam could not accompany his wife since he is on duty at a school. He is a teacher in a school, which is established to educate indigenous children who have been removed from their families. Besides, Sam worried to let his wife overseas since she is already in five-moth pregnancy.

However, his wife insists to go alone because she misses her parent so much and she has some friends who also want to come back to England. Reluctantly, Sam lets his wife go overseas by ship. At that time, his wife was twenty-five years old, ten years younger than him.

It is not more than a month after Sam permits his wife that her ship is hit by the strong storm. The ship, the captain, the crew, and all of passengers sank into the ocean. There is no body found alive. Sam gets this news from few passengers of another ship, which has just arrived, in Victoria.

All Sam can see in his mind's eye is his wife's pale face floating somewhere in the deep ocean. He cannot stop the tears gathering thickly in his eyes. It is hard to believe that his wife went too soon and left him with no children. Hence, Sam grows day by day so moody for next few years. $* 5 *$ 
Grandfather breaks the story for a moment and drinks a glass of water.

"I am sorry to hear that Grandpa,"says Paul.

"That's OK. I said the same thing to your great-grandpa," replies Grandfather.

"Do you want to know what happen then?"

"Of course, Grandpa."

$$
\text { *6* }
$$

One morning Sam is in the kitchen as he hears a girl's cry outside. Her voice crawls near the front window. He scampers along the house to open the front door. As he opens it, he sees a little girl whining "My ball! Mummy!"

Next to the girl is standing a pregnant woman. She is dressed in the white blouse and the white skirt. Her face is just like Sam's wife. His heart is pounding quickly.

The woman smiles and says, "Hi. I'm your new neighbour. I'm sorry to bother you at such a time. My daughter accidentally threw her favourite ball over your backyard fence. It may fall down into your garden."

"Oh, no worries! Let's take a look!"

First, there is no ball in the garden. The girl is still crying. The woman is searching for it by walking around the garden. Sam helps them. Suddenly, Sam notices a small green rubber ball behind the roses. He walks towards it immediately.

The woman touches the ball with her right hand. By chance, at the same time Sam puts his hand on her hand instead of picking up the ball. As Sam glances at the woman, he notices a gold wedding ring on her ring finger. It is similar to his wife's wedding ring.

Sam and the woman are nervous. "Oh, I'm sorry. I didn't mean it. I saw the ball, but suddenly you reached it first," Sam explains.

The little girl runs toward her mother. She claps her hands, jumps, and shouts excitedly "Hooray! Finally I get my ball."

"Let's go home!" the mother says to the girl.

"Please wait. Could we have those oranges, Mum!" the girl begs.

"You may pick up as many as you want, sweet girl!" Sam offers.

"Thank you. Actually we don't eat oranges," the woman sighs heavily.

"How about coming inside my house for a cup of tea?"

“Thank you. We're afraid we can't. There are so many things to do in our backyard and we have to clean up our house." delay you."

"It could take only a few minutes. That won't

"Well, actually we don't eat nor drink."

"Really? You must be kidding? Well, how about having a small chat?"

The woman blinks her eyes and nods her head gravely. "Well, it sounds interesting. I'd love to," she replies.

Simultaneously, she smiles very heartily at Sam; nobody else has done this since his wife has gone.

$$
* 7 *
$$

The woman and her son really do not touch the drink Sam has made for them. She keeps talking. "My husband has passed away. We've just moved here because we feel something calls us strongly from this area." The woman sighs.

'I'm sorry to hear that,' replies Sam.

"Thanks. Besides, we move here because I heard Moorabbin is quite safe area from polio epidemic. So, this area is safe for my daughter," adds the woman.

"Polio's too bad. It kills many children between the ages of five and ten years in many places."

"You're right. I hope the epidemic does not happen here and my daughter can stay healthy."

While Sam is listening to the woman, he notices something new in the living room. He moves out of the couch. He walks towards the old fashioned wooden table. The magnificent grandfather clock is standing next to the table.

"This's strange. This clock used to be in at the corner of this living room," Sam says.

"You know your house very well," the woman replies with a constrained smile.

"I don't understand how this clock could move next to this table?" Sam replies.

The woman walks toward the table and touches the clock. "Do you think so? It looks like the one that has been here for years," she says.

"I admire it and I am inevitably drawn to it," she adds.

Suddenly the woman's daughter yells "Mummy let's go home! I want to play outside!"

As they leave Sam is still curious about what has happened. He keeps thinking of them as he comes back toward the kitchen for more drink. When he comes back to the living room, he finds the grandfather clock is now in the position where it is used to be. He rubs his eyes.

$$
\text { *8* }
$$

The following morning Sam is looking for his cat. He has already prepared the food for it. But, it does not come. He is just about to go to John's house when he meets the same girl holding his ball in front of the door.

"Would you please help my mum?"

"What's happened to her?"

"She tripped on a wooden beam and fell down."

"Let's go, quickly!"

Sam steps into the neighbour's house and notices things around him. The open gate is old. It is swinging in the wind. The front yard is full of bushes. Old dry leaves straggle everywhere. Weeds grow up through the floorboard. Windows are broken. Spiders are making nests on the windows' frame.

"Where's your mum?" Sam asks the girl. 
"She's in the backyard. Please keep going!" the girl replies calmly. He walks in front of Sam.

Sam keeps his eyes scanning along the backyard. Rats are squeaking and they run into the bushes. Possums are jumping behind the gum trees. All of sudden, his attention is drawn to some black object. He approaches and touches it. It is a black cat. Upon his touching, the cat immediately arises, purrs loudly, and rubs against his hand. It is the cat which he was waiting for this morning - Sweet Black Catty. It jumps towards the girl when he wants to hold it.

Sam looks up to the sky. The sun is shining brightly. The thin clouds are moving slowly. The wind lightly touches his cheek like a feather drifting past him. He looks down. He sees his shadow on the ground, but he does not see the girls'.

"Help ...!" A voice breaks through Sam's personal silence. He sees the boy's mother stagger towards him. When he is about to hold her, the woman swoons and thuds on the ground. As he approaches her, Sam inhales the aroma of roses rising from her body. He touches her arms, but he feels nothing.

Meanwhile a lot of blood flow from the woman's legs. Therefore, it changes her white skirt into red. This scene somewhere reminds Sam of his late wife. Suddenly, the surroundings look too alien. The girl and the cat look smaller and smaller before they finally disappear in front of Sam.

Sam pinches his hand; it is painful. He is about to look for help as he feels his body becomes light and lifted by the wind.

$$
\text { *9* }
$$

"What happened next to the great-grandfather and his new neighbour?" Paul asks his grandfather. grandfather.

"Be patient! I am telling you further," replies the

$$
* 10 *
$$

Later, Sam finds himself on his bedroom. John is sitting beside his bed.

“Are you feeling better?” John asks.

"Err, yeah. Bit better now. Thanks, mate. How do you get here and what's happened to me?"

"Well. This morning, I was thinking about you and came to your house. In fact, you were not at home. I spoke to a man in the neighbourhood. He told me that he saw you entering the gate of the old house nearby alone. He called your name, but you couldn't hear him. Next, I looked for you and found you lying alone unconsciously on the ground.

"Where's the woman?"

"Which woman do you mean?"

"The one who's similar to my wife."

"There was nobody there, only you."

"She was seriously bleeding."

"I am so sorry, mate. You might be hallucinating again. Would you like a cup of tea?" John says. His wizened face breaks into a broader smile.

Sam drinks the warm drop of water and puts the cup down as John shows him something.

"Does this green ball mean something to you?"

"It belongs to the woman's daughter. How about the cat? Did you see it?"

Johns shakes his head.

"Let us go to the house once again, John! I'm pretty sure there are people in that house."

*11*

John and Sam are in front of the gate of the old house nearby. Sam cannot believe his sight as he looks at a new wooden billboard is standing in the neighbour's front yard. It says in a big capital letters F O R $\quad$ S A L E. The black cat is standing in front of it.

"Look at the cat! It's the one I told you about at home. Remember?"

"Where? I don't see it, only the billboard. It's not there yesterday, was it?"

"The house is going to be sold. Where have the woman and her daughter gone?" Sam asks.

John shrugs and says, "They're just your hallucinations, Sam. You should forget about them." John asks permission to go home.

Later in the afternoon, Sam tries to forget what has happened recently. He comforts himself by gardening in the backyard. Now and then he inhales the soft scent of the roses. Later, he pictures his wife while making a low humming sound under his breath.

Sam imagines she is alive and has given a birth to a cute healthy baby girl. Then, he draws himself holding the baby, bouncing him, and telling him about the things they can hear and see. He draws the baby growing into a healthy and pretty girl. Immediately, Sam pictures celebrating his wife's birthday at home. In his imagination, Sam sings the happy birthday song and he blows out the candles. He can see vividly in his mind that his wife gently kisses him and their daughter. Surely, his heart is warmer and he feels much better on that day.

$$
* 12 *
$$

"That's what Sam told me. He also wrote the same story in his diary. You may see it in my upper drawer," says Grandfather.

"I'll see it later, Grandpa. Now I'm curious to know how Sam could have a child," asks Paul.

"That's the most secret part. Years later, Sam adopted an indigenous girl baby who then became my wife. The baby was born by a very young mother who was raped in the farm by her landlord." The grandfather explained.

"The baby's mother became crazy because the one who raped her refused to take responsibility. She and her brother were taken away brutally from their original family by the people who had uniform for the reason of assimilation. At that time, they were less than eight years 
old. They were told to be educated, trained, and domesticated. Nevertheless, they were not allowed to meet their parents for the whole for their lives. As they grew up they did not know their original family." The grandfather continued.

"The brother of the baby's mother could not take care the baby because he had his own circumstance with his landlord. Besides, he worried about the epidemic of polio which was spreading in many areas. He met Sam by chance somewhere and asked his help for adoption. Sam agreed to adopt the baby for free." The grandfather adds.

"The baby girl grew up. She didn't realise that she's the adopted one until Sam told her when she was seven years old. Then she accepted the facts; grew up to become a beautiful woman; and got married to me." The grandfather continues.

You know, I'm not the first European man who legally wed an Indigenous woman. But, I am proud of our wedding. The first man who did is Robert Locke, a convict carpenter, who wed an Indigenous woman namely on 26 January 1824 at St John's Church, Parramatta." The grandfather ended his story.

"So, the adopted indigenous girl is my grandma?"

"You're right."

"It's hard to believe."

"It's true, Paul."

"Somehow it's like a nightmare."

"But, it truly happened, Paul. You know what; I feel a relief in my chest after telling you this fact." all? "

"So, Samuel is my adopted great grandfather after

“Exactly. Samuels' grief of losing his wife has made him to adopt your grandmother. He was the great one in his era."

“Well, I don't know what to say now, grandpa. I'm so sleepy now.”

"Good night, Paul!"

\section{REFERENCES}

[1] Australian Broadcasting Corporation, 2003, 'The Story of Maria Locke', (Online), Retrieved from $<$ http://www.abc.net.au/lateline/content/2003/hc48.htm> in August 2012.

[2] Bennett, Steve, 2009, 'Historical fiction genre definition', Retrieved from $<\mathrm{http}: / / \mathrm{www}$. findmeanauthor.com/definition _historical_fiction_genre.htm>inAugust 2012.

[3] Carroll, Richard, 2011, 'The Trouble with History and Fiction,' Journal of media and culture, Vol. 14, No. 3, (Online), Retrieved from

$<$ http://journal.media-culture.org.au/index.php/mcjournal/art icle/viewArticle/372> in August 2012.

[4] City of Kingston Historical Website, 2006, 'Poliomyelitis: Infantile Paralysis', Retrieved from $<$ http://localhistory.kings ton.vic.gov.au/htm/article/356.htm $>$ in August 2012.

[5] Dalton, H. Scott, 2006, 'What Is Historical Fiction?' (Online), Retrieved from $<$ http:// fmwriters. com/Visionback/Issue34/ historicalfic.htm $>$ in August 2012.

[6] De Piérola, José, 2008, 'At the edge of history: notes for a theory for the historical novel in Latin America', Romance Studies, Vol. 26, No.2, pp. 151-62.

[7] Hogle, Jerrold, 2002, The Cambridge Companion to Gothic Fiction, In Jerrold E. Hogle (ed.), Cambridge University Press, New York.

[8] Korff, Jens, 2012, 'A guide to Australia's Stolen Generations', (Online), Retrieved from <http://www.creativespirits.info/a boriginalculture/politics/a-guide-to-australias-stolen-generati ons\#toc7> in August 2012.

[9] Kurkowski, by Clifford J., 2012, 'The Gothic phenomenon in The Castle of Otranto: a critical essay', (Online), Retrieved from $<$ http://home.mindspring.com/ blkgrnt/ footlights/foot 51.html $>$ in August 2012.

[10] MacAndrew, Elizabeth, 1979, The Gothic Tradition in Fiction, Columbia UP, New York.

[11] Munslow, Alun, 2007, 'Presenting and/or re-presenting the past', Rethinking history: the journal of theory and practice, Vol. 11, No.4, pp. 517-524.

[12] Slotkin, Richard, 2005, 'Fiction for the Purposes of History', Rethinking history: the journal of theory and practice, Vol. 9, No.2-3, pp. 221-236.

[13] Walpole, Horace, 1998, The Caste of Otranto (1765), (E-book), Pennsylvania State University, US.

[14] Williams, Anne, 2000, 'Monstrous pleasure: Horace Walpole, opera, and the conception of Gothic', Gothic studies, Vol. 2, No. 1, pp. 104-118. 